\title{
Management of Learning for Children with Special Needs an Early Age
}

\author{
Lilis Suwandari ${ }^{1)}$, Sutaryat Trisnamansyah ${ }^{2)}$, Hanafiah $^{3)}$, Achmad Mudrikah ${ }^{4)}$ \\ 1) Universitas Islam Nusantara, Indonesia \\ 2.3,4) Administrasi Pendidikan Sekolah Pascasarjana Universitas Islam Nusantara Bandung, Indonesia \\ e-mail: email: lizsuwandari@gmail.com, sutaryattrisnamansyah@,uninus.ac.id, hanafiah@uninus.ac.id, \\ achmadmudrikah@yahoo.co.id.
}

Received: 11-07-2021 Revised: 30-10-2021 Accepted: 07-11-2021

Info Artikel Abstract

Keywords:

Learning Management, Children with Special

Need Early Age, Organizing.

Kata kunci:

Manajemen Pembelajaran, Anak Berkebutuhan Khusus Usia Dini,

Pengorganisasian.
This article aims to describe the concept and implementation of the management of learning for children of early age with special needs. This study systematically describes the facts found in the field and compare the conditions at both institutions verbal or sentence. Object in this research is the process of managing learning for children with special needs, early age to be a child. The process includes planning, learning, organizing, learning implementation, and supervision. methods of data collection using observation, interview and documentation. Managing learning in early childhood Bloom which combines between the child regular with children with special needs require a different management in early childhood education generally. Learning to accommodate children with different characteristics and barriers to the development of different. The results showed the presence of management learning for early childhood needs, namely in the planning of learning begins with the initial assessment to identify the peculiarities of the child to be tailored to the needs of the Program, Individual Learning in children as well as develop a curriculum that is used as a learning reference. Organizing by placing the supervising teacher or special teacher who has competence in the handling of the CREW in accordance with the division of the group of children's learning. The implementation of learning using learning model that is specified each institution, the implementation of learning activities include the opener, the core and the cover, Evaluation and assessment reports carried out to determine the development achieved in the learning process. Differences and similarities of both institutions are located on the concept and implementation in each of the management functions of learning for children with special needs. Recommendation addressed to the head of school, teachers and parents with the aim that the learning can be done well.

\footnotetext{
Abstrak

Artikel ini bertujuan untuk mendeskripsikan konsep dan pelaksanaan manajemen pembelajaran bagi anak usia dini berkebutuban khusus. Penelitian ini menggambarkan secara sistematis mengenai fakta-fakta yang ditemukan di lapangan dan membandingkan kondisi pada kedua lembaga bersifat verbal atau kalimat. Objek dalam penelitian ini adalah proses mengelola pembelajaran untuk anak berkebutuhan khusus usia dini yang menjadi anak. Proses tersebut meliputi perencanaan pembelajaran, pengorganisasian, pelaksanaan pembelajaran, dan pengawasan. metode pengumpulan data menggunakan observasi, wawancara dan dokumentasi. Mengelola pembelajaran pada PAUD Mekar
} 


\begin{abstract}
yang menggabungkan antara anak regular dengan anak berkebutuban khusus memerlukan pengelolaan yang berbeda pada PAUD umumnya. Pembelajaran mengakomodasi anak dengan berbagai karakteristik dan hambatan perkembangan yang berbeda-beda. Hasil penelitian menunjukkan adanya manajemen pembelajaran bagi anak usia dini berkebutuban yaitu pada perencanaan pembelajaran dimulai dengan asesmen awal untuk mengidentifikasi kekhususan anak untuk disesuaikan dengan kebutuban Program Pembelajaran Individual pada anak serta menyusun kurikulum yang digunakan sebagai acuan pembelajaran. Pengorganisasian dengan menempatkan guru pembimbing kbusus atau guru yang memiliki kompetensi dalam penanganan ABK sesuai dengan pembagian kelompok belajar anak. Pelaksanaan pembelajaran menggunakan model pembelajaran yang ditentukan masing-masing lembaga, pelaksanaan pembelajaran meliputi kegiatan pembuka, inti dan penutup, Evaluasi dan laporan penilaian dilakukan untuk. mengetahui perkembangan yang dicapai dalam proses pembelajaran. Perbedaan dan persamaan dari kedua lembaga tersebut terletak pada konsep dan pelaksanaan di masingmasing fungsi manajemen pembelajaran untuk anak berkebutuban khusus.Rekomendasi ditujukan kepada kepala sekolah, guru dan orang tua dengan tujuan agar pembelajaran dapat terlaksana dengan baik.
\end{abstract}

\title{
INTRODUCTION
}

Education is the basis for preparing the human quality. To create a generation that quality education should be implemented from an early age known as the Early childhood Education (PAUD), namely education is intended for children from birth up to the age of 6 years. Early childhood education has become very important to be implemented given the potential basis of the child and the basics of behavior are formed in this age range. Children at this age are experiencing aspects of rapid growth and development so that the required educational services (Fadillah \& Istikomah, 2021; Ilmi et al., 2021).

Need of educational services expressed in UUSPN No. 20 Year 2003 Article 1 section 1, Paragraph 14, that: "early childhood education is the development effort is aimed at children from birth until the age of six years is done through the provision of educational stimulation to help the growth and development of the physical and spiritual so that children have the readiness to enter further education".

The legislation suggests that early childhood education intended for all children including children with special needs (children who have vision problems, hearing loss, intellectual, social, emotional, and communication and social interaction) which requires stimulation through education in order to achieve maturity in the aspect of physical, motor, language, social, and emotional (Dayal \& Tiko, 2020; Kim, 2020; Pazeto et al., 2020).

Raw input; is a child with special needs, early age who have problems in learning as the impact of limitations. Impact such as: the ability of a intelekual limited, the lack of ability in the language, to communicate, socialize, work together, cognitive and emotional and others. Instrumental input is a Curriculum, Programs, methods of teaching as well as APE (Tools Educational Game/alat peraga edukasi)(Dewi, 2021; Kencono \& Winarsih, 2021; Mursalin \& Setiaji, 2021).

Enviromental input, the role of the environment in formulating the management of learning for children with special needs, early age like: the family, the community, the role of parents, the school committee (Asmarani et al., 2021; Ikramullah \& Sirojuddin, 2020). Process, is the activities in the learning management children with special needs, early age, which include: planning, organizing, implementing, controlling/directing, and assessment (Muslimin \& Kartiko, 
2020; Yuwandra \& Arnawa, 2020).

Output, is the realization of the management of learning for children with special needs, early age, which is expected to achieve the optimization of the learning, well-trained physical and non-physical are prepared with attention to real conditions and theories related and the existence of children with special needs in early childhood education, held test validation and ready to be implemented. Out comes, the presence of recommendations that wants to learning for children with special needs, early age are ready to learn (Sidat, 2021) (Hapsari et al., 2020; Hasanah, 2021).

Given the extent of the problem formulated, the researcher limit the issues related with Planning, Organizing, Implementation, Assessment and Monitoring and follow-up. Learning for early childhood perceived not optimal to raise the child with special needs, early age are ready to learn in early childhood Mekar Kecamatan Rancasari Kota Bandung.

In this study the focus is to describe about the management of learning for children with special needs early childhood in early childhood Mekar Rancasari District Bandung City. include: planning, organizing, implementation, assessment and supervision of learning. The difficulties encountered in carrying out the management of learning for children with special needs early childhood and efforts to overcome the difficulties encountered in carrying out the management of learning for children with special needs an early age.

\section{RESEARCH METHODS}

Approaches and research methods important diperhatikann because the approach and methods will lead researcher on the purpose of the research. In other words, the selection of the approach and methods to be precise, according to the problems to be studied so that the research objectives can be achieved.

Based on this understanding, this study was conducted using a qualitative approach which is often also called the naturalistic paradigm is an approach that emphasizes the nature of the relationship between the researcher and the data source. In this case, the researchers also plays a role as an instrument of research (human instrument) go directly to the field to collect a variety of data according to the interests/needs of the research.

By synthesizing the opinion of some experts, (Moleong, 1989) suggests the following: Qualitative research is a research that intends to understand the phenomenon of what is experienced by research subjects, for example the behavior, perception, motivation, action, and others, in a holistic manner, and by way of description in the in the form of words and language, in a specific context that naturally and by using various scientific methods.

Some of the characteristics of qualitative research relevant to the problems studied in this research, among others: the natural background, the human as a tool (instrument), data analysis is inductive, descriptive, more concerned with process than on the outcome, and others.

In accordance with the objectives to be achieved, the researcher used descriptive method. The goal of a study is to obtain data by means of scientific which is then processed and analyzed so as to obtain a conclusion. Thus, in carrying out this research, the researcher used a qualitative approach-descriptive. Presented by (Sukmadinata, 2005) that; a descriptive-qualitative Research pay more attention to the characteristics, quality, linkages between activities. More was stated that in the field of education, with this approach, researchers describe the phenomena of educational activity, learning, and implementation of the curriculum in a variety of types, levels, and education units. 
Through this approach the researcher seeks to explore a variety of data and information that are relevant to the interests of research, both in theoretical form of the study of literature and empirically based on early studies in the field. Regarding this, the researcher refers to the opinion (Creswell, 2012) as follows:

"descriptive research, used in early research to collect data about existing conditions, such as: (a) the condition of the product-a product that already exists as a comparison material or base material (embryos) for products that will be developed. (b) the condition of the users of the product, such as schools, teachers, principals, and students, (c) the condition of the factors supporting and inbibiting the development and use of the product to be produced, includes an element of human, infrastructure, cost, management, and environment".

Based on the opinion above, the researcher collect/record data without any engineering and manipulation of data through observation, interview, and documentary study related to management learning early childhood with special needs.

\section{RESULTS AND DISCUSSION \\ RESULTS}

\section{Planning Learning}

Introduction differences in the ability of the individual child has not been implemented optimally. This is due to the instrument identification that teachers do not yet skilled at creating and implementing identification. Similarly, the assessment, the school (teacher) does not have the instruments of assessment which is needed as a tool to determine the ability of the child which was subsequently used as a basis to develop the program (Gentry \& Paul, 2014).

Started by compiling teaching material (Thematic, LESSON plan, Syllabus) are still common, the intention has not been to answer the learning needs of children with special needs. This is due to the teacher not have a device that assessment is adequate and the shape/pattern of teaching materials that were sent from the center of the lead teacher to work in accordance with those patterns.

Program Individual Learning, task Analysis has not been done well. This is caused by the lack of understanding and skills of teachers in preparing instructional materials such. The linkages and the integration of field studies, the topic, the material with the environment, the advancement of education and technology has not been realized with optimal because of the topic or the material in the teaching materials are still the same with teaching materials for children in general. Example, the determination of the theme as a hook not see the significance of the theme/hook it's for the child berekbutuhan special early age.

The analysis of the curriculum has not been done by the school/teachers so that the child is given the same subject matter with his classmates. Still rare for the school to formulate a curriculum of its own in accordance with the needs of the child, especially for children with special needs an early age.

Identification and detection of children with special needs, early age, can be viewed at the planning stage as in the table below: 
Table 1 Identification and Detection of Children with Special Needs an Early Age

\begin{tabular}{|c|c|c|c|c|}
\hline No & Behavioral Indicators & 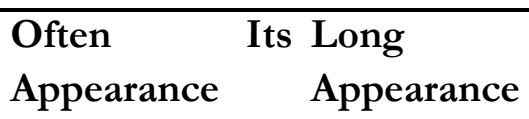 & Alleged & Description \\
\hline 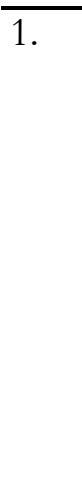 & $\begin{array}{l}\text { Abnormalities Intelligence } \\
\square \text { Silent hours } \\
\square \text { Shy away from the act } \\
\text { of thinking } \\
\square \text { Response to the speech- } \\
\text { language late/less } \\
\square \text { Can say not able to do } \\
\square \text { Play with a child who is } \\
\text { younger than her age }\end{array}$ & & & $\begin{array}{l}\text { At least the } \\
\text { appearance } \\
\text { of } \\
\text { symptoms } \\
\text { to } 3 \mathrm{x}\end{array}$ \\
\hline 2. & $\begin{array}{l}\text { Abnormalities In Autism } \\
\square \quad \text { Difficult to respond } \\
\text { when called upon his name } \\
\square \text { Very little eye contact } \\
\square \text { Refused to be hugged } \\
\text { and kissed } \\
\square \quad \text { Feel 'comfortable' with } \\
\text { the play itself, usually has a } \\
\text { 'friend play the delusion' } \\
\square \text { Not make eye contact } \\
\text { when ask for something } \\
\square \quad \text { Can not start a } \\
\text { conversation or continuing } \\
\text { it } \\
\square \text { Perform movements are } \\
\text { repeated, such as swaying, } \\
\text { spinning, and clap your } \\
\text { hands } \\
\square \quad \text { May be fascinated by } \\
\text { parts of an object, such as a } \\
\text { spinning wheel toy car } \\
\square \text { May be very sensitive to } \\
\text { light, sound and touch, and } \\
\text { yet don't realize the pain } \\
\square \text { Not sensitive to danger } \\
\text { and pain }\end{array}$ & & & \\
\hline
\end{tabular}

Characteristics of subject matter in accordance with the state children with special needs, early age is not yet clear. The subject matter of children with special needs early age adjusted with birth age (calendar age). This resulted in a kid always having difficulty or not able to learn because the material was not in accordance with the age of intelligence. 


\section{Organizing Learning}

Organizing learning begins by combining field studies, the topic, the material with the ability of students, the advancement of education, and the technology has not been implemented optimally. Included in analyzing the curriculum that have not yet done so that there is a tendency that the child is given the same program with the got adaptation or modification.

The placement of the children in the class based on the age of intelligence, so that there will be an imbalance of physical, anak tunagrahita ringan with the age of his intelligence 5 years of age their 7 years, so also with children who have communication disorders of social interaction, equated its placement such a plain child.

In carrying out the organization of the field of study and learning materials determine the relationship and the integration of all subjects. In carrying out the organization of the field of study of the difficulties faced by all informants expressed specify the field of study that is almost the same with learning skills, so that it can determine the topic of skills. As well as the significance for the child.

\section{The Implementation Of The Learning}

The implementation of the learning difficulties faced that is to create a learning environment and follow-up; as well as opening and closing the learning, the limitations of the infrastructure and create a comfortable learning atmosphere, such as the condition of the child to be ready to learn, the mood of the child is uncertain, and brought the child to the learning situation.

Encouraging children's learning motivation, creating a readiness to learn, and develop learning individually; the Difficulties experienced in closing the learning difficulty when the condition of the child back to the original situation because the kids already want to go home soon. Review the learning so that the child always remember learning that has been done with the method of playing so that students are comfortable and keep the spirit of learning.

In the implementation of the learning needed for completeness and variation of the shape of the teaching materials given the ability of children with barriers intelligence. interaction and communication are different. Therefore learning must be packaged in the form of thematic learning program individually, analaisiss task, and RPP kesemuaanya it must express the need of the existence and needs of children with barriers intelligence. interaction and communication.

\section{Assessment Of Learning}

The implementation of evaluation of the learning only uncover the learning outcomes of the child that note, how this can not describe the ability of children with special needs, early age be based on the difference between intra and inter individual. In addition, it has not been done the assessment of inter-linkages or integration between planning, organizing, implementation, and supervision of learning.

Because in determining the techniques and timing of the assessment, the scope of the assessment, and recommendation the results of the assessment and the learning objectives should be implemented individually based on the abilities of the child; not just the pursuit of achievement, but developing aspects of attitudes, knowledge, and skills.

Assessment is done at the time of learning, because the learning process is done and in the process can provide an assessment whether the child is capable of in such material or not. 
Furthermore, the assessment made in the form of descriptive or the portfolio so that it can be seen the ability of the child clearly.

Supervision is a lot of watching (hold monitoring, supervision) on the administration of the learning process rather than supervision in planning, organizing, implementation, and assessment of learning.Analysis of individual differences of children executed before compiling the program and during the learning process takes place. Executor is a teacher and the head of the school. Instrument identification and assessment have been there in the school in the form of observation and assessment.

Because of the tragedy of the child's learning with obstacles intelligence. interaction and communication which contains about prncanaan, organizing, implementation, assessment and supervision.

\section{DISCUSSION}

On the level of early childhood handling children with special needs, early age can dititkberatkan on the development of skills to socialize and effectiveness of the aids themselves are simple. When dealing with children with special needs early childhood personality pendidikpun should be strengthened, early childhood educators should be aware that the sedenga faced is a child who needs attention and special treatment. Educators need to be able to sincere and be patient if the child does not behave as expected.

In dealing with children with special needs early childhood education for pre-need management that the implementation of learning can be achieved optimally. Objective conditions of learning for early childhood with obstacles intelligence, social interaction and communication in accordance with the learning management is not optimal.

Components of lesson planning activities conducted by mapping differences in the ability of the child is not yet implemented in the school, using the tool of identification and assessment have not owned by the school, then draw up a learning device that is not based on the results of the assessment with the see learning program has not been associated with environmental conditions that exist in the school so that the child is not ready in the study and Planning of learning created integrated with other subjects, so the teacher only uses the teaching materials which are prepared in the form of RPP and yet coloring differences in the ability of the child.

In the aspect of organizing the field of learning and learning materials. The factors that need to be considered in organizing the field of study is all informants stated usefulness in children with special needs an early age. Learning materials for children have usefulness of learning materials for children and similarity indicators. The officer who mengorganisis learning materials is all the teacher and the supervising teacher special.

The implementation of learning is to prepare a learning environment, implementing the initial activities, core activities and the activities of the end of the activities, as well as the followup.

The initial Activity: Preparing children diasesmen, fill out the attendance list, describes the way the assessment is made.

The core Activities of the: Direct children of the given task and working on such tasks. When the child is having difficulty given the opportunity to repeat it twice or by simplifying the material/task. Must be considered that the child is not given an explanation or taught first but boy was given the task in accordance with the assessment instruments (worksheet learners). 
The final Stage: After the assessment is completed then the assessor/tutor to calm the child and return to home or to class. The implementation of the assessment, the steps or procedures for the implementation of the assessment can be seen on-like the table below:

Table 2 Assessment Development

\begin{tabular}{ll} 
Name & \multicolumn{1}{c}{$:$} \\
Age & $:$ \\
Type Of Abnormality $\quad:$ & The age of the child $\quad$ The development of fine motor \\
\hline Age 5 years & Play with block design \\
& $\square$ Know of 7 to 8 forms with the touch of a \\
& $\square$ Explain the number of fingers on each hand \\
& $\square$ Fond of imitating the form of a simple \\
& $\square$ Drawing on the floor and on the paper \\
& $\square$ Make streets and houses with sand \\
& $\square$ Making objects with clay/wax \\
& $\square$ Arranging the blocks: make roads, buildings \\
& $\square$ Fond of coloring, make a line, cut, stick \\
& $\square$ Make a square \\
& $\square$ Create a vignette and feel the cuteness. \\
& $\square$ Print some large letters \\
& $\square$ Draw people he knew
\end{tabular}

The form of task Analysis is a procedure that can be used to teach a specific task and is needed in the learning of children with mental retardation because it is not able to learn the task great or general nature. The weight ketungagrahitaan then the more detailed or more of the analysis task and vice versa the rngan ketunagrahitaan then the little details of their duties.

Principles of preparation of task analysis with attention to the subject, determine the purpose to determine the capabilities that are expected to be achieved at the end of the program and divides the task into the task that is small. These principles need to be considered in drawing up and carrying out the analysis task. As in the table below:

Table 3 the Analysis of the Task of Wearing socks

\begin{tabular}{|c|c|c|c|}
\hline No & Aspects are Analyzed & $\begin{array}{l}\text { Maximum Can } \\
\text { Score }\end{array}$ & $\begin{array}{l}\text { Can be Can be Can not } \\
\text { with the with the be } \\
\text { help of help of } \\
\text { verbal physical }\end{array}$ \\
\hline 1. & Take socks & & \\
\hline 2. & $\begin{array}{l}\text { Hold the socks with both } \\
\text { hands }\end{array}$ & & \\
\hline 3. & $\begin{array}{l}\text { Enter t-shirts right foot to } \\
\text { foot next to right }\end{array}$ & & \\
\hline 4. & Interesting socks right up & & \\
\hline
\end{tabular}


Follow-Up :

Description : maximum Score is determined self/teacher

Assessment criteria :

$4=$ can

$3=$ can with the help of verbal

$2=$ can with the help of physical

$1=$ can not

Final Value

Score gains : maximum Score $\mathrm{x} 1$

Learning Implementation plan (RPP) given to children with mental retardation is the same with lesson plans that apply to ordinary boy. Just in RPP children with mental retardation need to formulate ketentun special provisions in accordance with the existence of children with mental retardation, such as in the formulation of the indicators should pay attention to the difference in inter and intra children with mental retardation, learning objectives must be dirumusakan in accordance with the kepberadan each child, the formulation of the learning activities should also be determined based on the difference in every child; and evaluation should be based on what is learned by every child with special needs an early age. As the format of the RPPH Thematic below;

Table 4 RPPH Thematic

Theme : Health (brushing Teeth) adaptation of the Nani (2015:27-33)

Subjects : : Self-Development, Bahasa Indonesia, IPA, Mathematics

Class/Semester :

Time

The Core competence, Basic Competence, the Syllabus Analyze the KD and Indicators

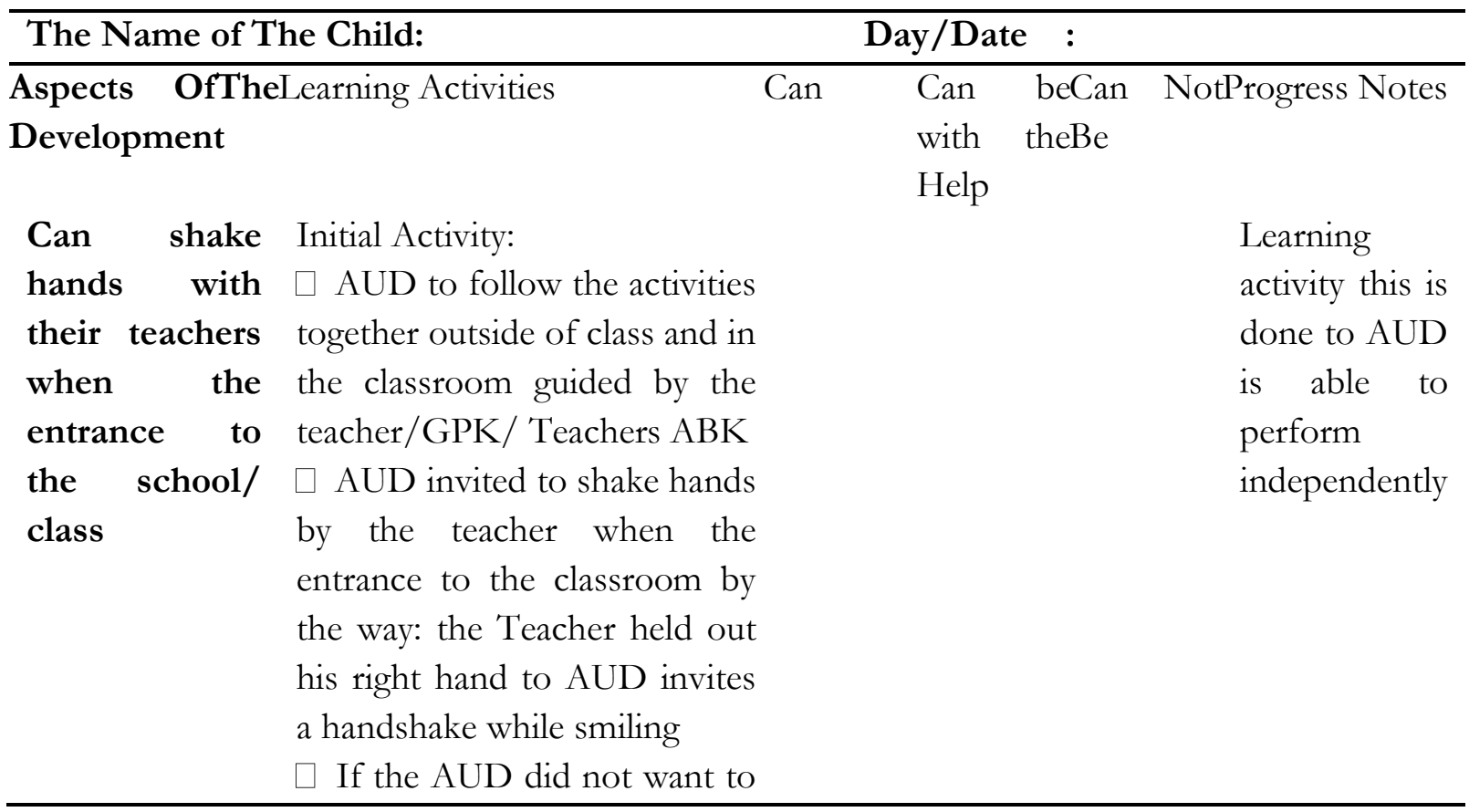




\begin{tabular}{ll}
\hline & reward a helping hand the \\
& Teacher then the teacher takes \\
the right hand of the AUD to & held while smiling \\
Can shake & Core Activity: \\
hands with his & AUD guest along with the \\
friends & AUD others in the room. In \\
& this activity, teachers can \\
& create activities which involves \\
& a handshake between AUD \\
& (shaking hands) \\
\hline
\end{tabular}

Form a team of PPI that consists on teacher class, teacher field of studies, head of the school, the Teacher Companion Specific (GPK), the elderly or the energy of the other members there and associated with the condition of the child. Tim PPI is responsible for the planned program together, such as: Evaluate the strengths, weaknesses, interests and needs of children from different aspects of the development of; emotions, socialization, cognitive, language, physical motor, and others as well as specialized programs, expand the purpose of the long-term and short-term goals, planning methods and procedures the achievement of the purpose of, and determine the methods of evaluation that can be used to determine the child's progress.

\section{CONCLUSION}

Based on the findings of the study research introduction along with the theories associated with the management of the learning conditions of children of early age with obstacles intelligence, social interaction and communication. The Input is a child with obstacles intelligence. Social interaction and communication (early age) and teachers. Environment (family environment, social environment, school environment and school committee). The ability of the child early childhood with obstacles intelligence, social interaction and communication is not yet known with certainty because it is needed in the assessment. The focus of study in this research is the learning management early childhood with obstacles intelligence, social interaction and communication that do not yet have a special study in accordance with the needs of the child. The contents of the study cover aspects (planning, organizing, implementation, assessment, and supervision). Planning learning discuss the differences in the ability of each child, develop and implement the assessment of abilities, preparing teaching materials. Learning organizing discuss the integration of the program with the field of studies or material associated with the condition of the child and the environment. Assessment of learning discuss about the assessment process and the assessment results as well as the linkages between the components of learning management. Supervision of learning discuss the activities of monitoring and supervision. Output, contains the expected results of optimizing the development of potential CREW an early age and Outcomes, the creation of learning can prepare children to learn effectively. 


\section{REFERENCES}

Asmarani, A., Sukarno, S., \& Widdah, M. E. (2021). The Relationship of Professional Competence with Teacher Work Productivity in Madrasah Aliyah. Nidhomul Haq : Jurnal Manajemen Pendidikan Islam, 6(2), 220-235. https://doi.org/10.31538/ndh.v6i2.1365

Creswell, J. W. (2012). Qualitative Inquiry and Research Design: Choosing Among Five Approaches. SAGE Publications.

Dayal, H. C., \& Tiko, L. (2020). When are we going to have the real school? A case study of early childhood education and care teachers' experiences surrounding education during the COVID-19 pandemic. Australasian Journal of Early Childhood, 45(4), 336-347. https://doi.org/10.1177/1836939120966085

Dewi, N. C. (2021). Individual Differences in Developmental Psychology Early Childhood Mentality. Naz̧hruna: Jurnal Pendidikan Islam, 4(2), 447-459. https://doi.org/10.31538/nzh.v4i2.1594

Fadillah, D. P., \& Istikomah, I. (2021). The Strategy Of School Literacy Culture In Elementary School. Nazhruna: Jurnal Pendidikan Islam, 4(3), 503-517. https://doi.org/10.31538/nzh.v4i3.1614

Gentry, M., \& Paul, K. A. (2014). Developing a Professional Learning Plan to Support TSCG Implementation: Supporting Teachers and Educating the Community. In Total School Cluster Grouping \& Differentiation (2nd ed.). Routledge.

Hapsari, S. M., Sugito, S., \& Fauziah, P. Y. (2020). Parent's Involvement in Early Childhood Education during the Covid-19 Pandemic Period. Jurnal Pendidikan Progresif, 10(2), 298311.

Hasanah, M. (2021). The Role of Parents in Children Memorizing the Qur'an in Middle School Based on the Amanatul Ummah Islamic Boarding School. Tafkir: Interdisciplinary Journal of Islamic Education, 2(2), 139-156. https://doi.org/10.31538/tijie.v2i2.43

Ikramullah, I., \& Sirojuddin, A. (2020). Optimalisasi Manajemen Sekolah Dalam Menerapkan Pendidikan Inklusi di Sekolah Dasar. Munaddhomab: Jurnal Manajemen Pendidikan Islam, 1(2), 131-139. https://doi.org/10.31538/munaddhomah.v1i2.36

Ilmi, M. U., Setiawan, F., Hikmah, M. N., Kharisma, A., Feryawan, D., \& Hanafie, A. A. (2021). The Basic Concepts of Evaluation and Its Implementation in IRE Lessons in The Pandemic Era. Tafkir: Interdisciplinary Journal of Islamic Education, 2(2), 175-190. https://doi.org/10.31538/tijie.v2i2.50

Kencono, D. S., \& Winarsih, A. S. (2021). Pemanfaatan Barang Bekas sebagai Alat Peraga Edukasi Ramah Lingkungan Sekolah PAUD di Kota Yogyakarta. PengabdianMu: Jurnal Ilmiah Pengabdian Kepada Masyarakat, 6(3), 291-297. https://doi.org/10.33084/pengabdianmu.v6i3.2082

Kim, J. (2020). Learning and Teaching Online During Covid-19: Experiences of Student Teachers in an Early Childhood Education Practicum. International Journal of Early Childhood, 52(2), 145-158. https://doi.org/10.1007/s13158-020-00272-6

Moleong, L. J. (1989). Metodologi penelitian kualitatif. Remadja Karya. 
Mursalin, E., \& Setiaji, A. B. (2021). Pelatihan Pembuatan Alat Permainan Edukatif (APE) Sains Sederhana bagi Guru PAUD. BAKTIMAS : Jurnal Pengabdian Pada Masyarakat, 3(4), 140 148. https://doi.org/10.32672/btm.v3i4.3561

Muslimin, T. A., \& Kartiko, A. (2020). Pengaruh Sarana dan Prasarana Terhadap Mutu Pendidikan di Madrasah Bertaraf Internasional Nurul Ummah Pacet Mojokerto. Munaddhomah: Jurnal Manajemen Pendidikan Islam, 1(2), 75-87. https://doi.org/10.31538/munaddhomah.v1i2.30

Pazeto, T. de C. B., Dias, N. M., Gomes, C. M. A., \& Seabra, A. G. (2020). Prediction of Reading and Writing in Elementary Education through Early Childhood Education. Psicologia: Ciência e Profissão, 40. https://doi.org/10.1590/1982-3703003205497

Sidat, I. (2021). Critically Explore Perceptions of Human Development in Classical Muslim Educational Thought and Discuss its Implications for Contemporary Islamic Education. Naz̧hruna: Jurnal Pendidikan Islam, 4(1), 32-45. https://doi.org/10.31538/nzh.v4i1.1155

Sukmadinata, N. S. (2005). Metode penelitian pendidikan. Program Pascasarjana Universitas Pendidikan Indonesia dengan PT Remaja Rosdakarya.

Yuwandra, R., \& Arnawa, I. M. (2020). Development of learning tools based on contextual teaching and learning in fifth grade of primary schools. Journal of Physics: Conference Series, 1554(1), 012077. https://doi.org/10.1088/1742-6596/1554/1/012077 